Article

\title{
We're Not Doing Enough Prescribed Fire in the Western United States to Mitigate Wildfire Risk
}

\author{
Crystal A. Kolden (1) \\ Department of Forest, Rangeland, and Fire Sciences, University of Idaho, 875 Perimeter Dr. MS 1133, Moscow, \\ ID 83844, USA; ckolden@uidaho.edu; Tel.: +1-208-885-6018
}

Received: 28 April 2019; Accepted: 21 May 2019; Published: 29 May 2019

\begin{abstract}
Prescribed fire is one of the most widely advocated management practices for reducing wildfire hazard and has a long and rich tradition rooted in indigenous and local ecological knowledge. The scientific literature has repeatedly reported that prescribed fire is often the most effective means of achieving such goals by reducing fuels and wildfire hazard and restoring ecological function to fire-adapted ecosystems in the United States (US) following a century of fire exclusion. This has translated into calls from scientists and policy experts for more prescribed fire, particularly in the Western US, where fire activity has escalated in recent decades. The annual extent of prescribed burning in the Western US remained stable or decreased from 1998 to 2018, while 70\% of all prescribed fire was completed primarily by non-federal entities in the Southeastern US. The Bureau of Indian Affairs (BIA) was the only federal agency to substantially increase prescribed fire use, potentially associated with increased tribal self-governance. This suggests that the best available science is not being adopted into management practices, thereby further compounding the fire deficit in the Western US and the potential for more wildfire disasters.
\end{abstract}

Keywords: indigenous burning; traditional ecological knowledge; wildland fire; controlled burning; prescribed burning; Cerro Grande

\section{Introduction}

Recent disastrous and fatal wildfires across the United States (US) have yielded renewed calls to reduce the wildfire hazard [1-4]. One of the primary hazard reduction strategies identified in the scientific literature is prescribed burning - the intentional ignition of controlled fire, which is also referred to as prescribed fire or controlled burning in the US [5]. Prescribed fire not only reduces the biomass available to burn in a subsequent uncontrolled wildfire [5-7], it also supports carbon sequestration [8,9], facilitates ecological resilience [10-12], and is critical in restoring ecological function in regions where decades of fire exclusion pushed fire-adapted ecosystems outside their historic range of variability and degraded such function [12-14]. As anthropogenic ignitions and climate change have enabled the expansion of the fire season and larger and more disastrous wildfires [15-18], many of the recent high-profile scientific syntheses and perspectives have specifically advocated for increased use of prescribed fire $[1-4,19,20]$. Similarly, the US National Cohesive Wildland Fire Management Strategy (hereafter, Cohesive Strategy)—a planning effort stemming from the 2009 FLAME Act—specifically identified prescribed fire as the most cost-effective solution over the largest potential area of the US, as compared to managed wildfire and non-fire vegetation treatment [21]. Both the best available science and guiding policy documents in the US support more prescribed fire, but there has been limited assessment of whether this is translating to practice.

The intentional use of fire across landscapes has a long history in the US that is rooted in both the widespread indigenous burning practices of many North American tribes and the use of fire as a land-clearing tool by settlers prior to the 20th century [22]. At the onset of the 20th century, 
perceptions about intentional burning underwent a fundamental shift, particularly in the Western US, where large wildfires threatened lives and timber resources and cultivated modern US wildfire policies [23]. Science-based efforts to restore fire to Southeastern forests were underway by the 1930s, while prescribed fires and natural wildfire were reintroduced into Western national parks and wilderness areas in the 1960s [22]. In parallel, American Indian tribes have sought to reintroduce fire, both to reclaim sovereignty through self-governance of tribal lands and to maintain important tribal cultural components [24-26]. There is also recognition that considerable extant traditional ecological knowledge (TEK) surrounding fire and indigenous controlled burning practices persists in native communities throughout the US [25]. This indigenous knowledge is a rich potential source of information and strategies for implementing more prescribed fire through collaborative partnerships with tribes, but remains underutilized [25-27].

As has been widely documented, prescribed fire is not without drawbacks. Prescribed fires produce smoke, which can violate air quality regulations and has negative impacts to human health [28-30]. Prescribed fires infrequently escape to become wildfires. Perhaps the most notable of such incidents was the 2000 Cerro Grande Fire, which began in early May as a prescribed fire at Bandolier National Monument in New Mexico but escaped to become a 19,000 ha wildfire. The Cerro Grande Fire consumed 235 homes [29] and subsequently shut down nearly all federal prescribed burning in the US for several months. These potential negative effects translate to social perceptions that provide considerable barriers to the widespread use of prescribed fire [30]. A considerable challenge for science has been to accurately assess the trade-offs of prescribed fire versus wildfire, particularly as wildfires occur relatively infrequently for a given location and indirect or secondary wildfire effects are difficult to quantify.

A Web of Science search of refereed literature of the terms "prescribed fire", "controlled burning", and "prescribed burning" demonstrates that over the past century, 4275 total refereed indexed papers were published that addressed prescribed fire in the US (Figure 1), with only one prior to 1972. There is a significant positive trend during this period as the literature expands around prescribed fire and controlled burning. It covers a broad range of topics, but the literature is overwhelmingly associated with Environmental Sciences and Ecology (85\%), with only a small proportion affiliated with relevant disciplines such as Business/Economics (6\%), Public Health (5\%), Water Resources (4\%), Engineering (3\%), and Social Sciences (1\%). Notably, while earlier literature focused on prescribed fire as a tool to restore fire excluded from so-called "fire-prone" forests (i.e., historically high-frequency and low-severity fire forests), more recent literature has investigated the use of controlled burning across a range of ecosystems to reduce hazardous fuels, not just forests considered prone to fire.

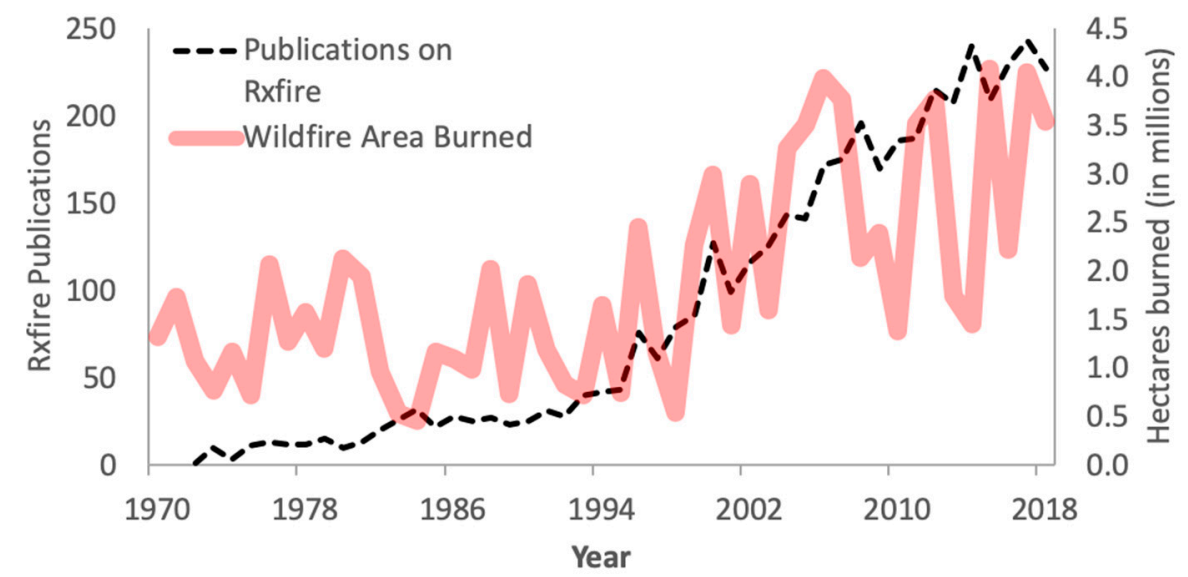

Figure 1. Annual publications on prescribed fire (dashed black line) and annual area burned (red solid line) for the United States (US), 1970 to 2018. 
This trend towards increased understanding of prescribed fire should theoretically support its increased application, and such application is sorely needed. In the US Pacific Northwest, Haugo et al. [31] reported that for the 31-year period between 1984 and 2015, wildfire burned just 1.6 mill ha across a subset of forests in Washington and Oregon. This total was an order of magnitude less than the 15-21 mill ha expected under historical fire regimes and in the absence of fire suppression and exclusion. This deficit included 7-10 mill ha of the type of low-severity fire that prescribed burning can replace or be used to restore ecological function [31]. Other more general studies have similarly reported widespread wildfire deficits across western US forests [32]. To date, however, there has been little assessment of changes in US prescribed fire use in response to increased understanding of both its effects and the broader fire deficit.

My primary objective was to assess whether the US federal land management agencies are translating the best available science and current national fire policies into the increased use of prescribed fire. I also sought to assess regional and agency differences in order to understand which regions and agencies are increasing their prescribed fire accomplishments, as would be expected given the increased emphasis in both the scientific literature and policy. The adoption of increased prescribed fire use may be a key indicator of sociocultural acceptance of fire, which is a critical first step in effectively reducing wildfire vulnerability [20].

\section{Methods}

I evaluated trends in the application of prescribed fire in the US from the National Interagency Fire Center (NIFC) Situation Report (SIT Report) Archives and Historical Wildland Fire Summaries (available at www.nifc.gov). The annual Historical Wildland Fire Summary reports published by NIFC list both wildfire and prescribed fire accomplishments for each state stratified by federal agency (or non-federal entities), and date back to 2002 (but do not include prescribed fire in 2018). The SIT Report Archive includes the daily (during peak US fire activity) to weekly (during low fire activity) reports of large fires, cumulative wildland fires and area burned, and cumulative prescribed fires and area burned from 1998 to present. I utilized the cumulative prescribed fire data included in the last published SIT Report for each calendar year for the temporal analysis, and the Historical Wildland Fire Summaries to explore state-level trends.

For each Geographic Area (as defined by NIFC), more commonly referred to as a Geographic Area Coordination Center (GACC) region, I calculated a Spearman's Rho (years versus area) to assess trends, the annual mean accomplishment for a given GACC (ha/year), the trend or slope (mean change in ha/year from 1998 to 2018), the relative trend as a percent based on the mean accomplishment of a GACC (slope/mean accomplishment * 100), the percent of the US total 1998-2018, and the percent of the US trend 1998-2018. As GACCs vary widely by size and the amount of land managed by various agencies (Table S1), I also calculated an area weighting for the annual mean accomplishment by GACC and agency to normalize by area. Similarly, I calculated these metrics for each agency class. The five primary federal land management agencies that manage wildfire are each an individual class (i.e., the Bureau of Indian Affairs (BIA), the Bureau of Land Management (BLM), the Fish and Wildlife Service (FWS), the National Park Service (NPS), and the US Forest Service (USFS)), while a sixth class denoted as "State/Other" (ST/OT) includes any entity reporting that does not fall under the five primary federal agencies. This includes both other federal agencies that accomplish substantial prescribed fire, such as the Department of Defense (DOD) on military installations, the Department of Energy (DOE), the Bureau of Reclamation (BOR), as well as both state and even some private/non-profit entities where state agencies complete and report accomplishments (Table S1). I did not limit the analysis to any one ecosystem or fire regime type (e.g., historically fire-prone forests). As noted previously, more recent literature and management policies such as the Cohesive Strategy do not limit prescribed fire as a hazard reduction tool to any ecosystem. 
The SIT Report Archive is not perfectly equivalent to the annual Historical Summaries because the data were not yet assessed for quality control, and also because the last report of the year was often published prior to December 31 (so additional accomplishments may have been reported in the last few days of the year). However, because the Archive dates back to 1998, it provides four additional years of data in a relatively short time series. The annual prescribed fire totals for the SIT Report final report of the year and the official totals provided in the Historical Wildland Fire Summaries are nearly equivalent for the 2002-2017 overlap period $\left(r^{2}=0.9992\right)$. It should be noted that while these data can include prescribed burns conducted by private entities working with agency partners, they largely exclude the type of broad-scale private lands burning that occurs in grasslands and rangelands (e.g., the annual pasture burns across the Flint Hills region of Eastern Kansas).

\section{Results}

As recorded in the National Interagency Fire Center Daily Situation Reports, fire agencies completed a reported 23 million hectares of prescribed fire (averaging just over 1 mill ha per year) over the period 1998 to 2018, and annual totals increased by an average of 61,678 ha (mean 5\% annual increase) per year (Table 1, Figure 2). However, $70 \%$ of all prescribed fire and $98 \%$ of the increase over time was observed in the Southeastern US Geographic Area (Figure 2a,c). Of the remaining nine Geographic Areas of the US (as delineated by the National Interagency Fire Center), only three reported an increase in prescribed fire over the period of record (Figure $2 b, d$ ), while the remainder reported a decrease. Excepting a strong increase in prescribed fire in the Eastern GACC and a strong decrease in the Great Basin, however, the slopes for all other units were so small that they were essentially rendered flat, even when the GACCs were normalized by area. This is particularly reflected in rank correlation coefficients, where only the Southern, Eastern, and Great Basin GACCs demonstrated a strong trend (i.e., a Spearman's Rho value greater than 0.5) (Table 1).

Table 1. Trends in prescribed fire accomplishments in the United States (US) by Geographic Area Coordination Center region (GACC) from 1998 to 2018, including raw trend (mean ha/year), relative trend (normalized by mean accomplishment for a given GACC), percent of the total US accomplishment, percent of the total US trend, and Spearman's Rho to indicate the strength of the trend.

\begin{tabular}{cccccc}
\hline GACC & Trend (ha/yr) & Rel. Trend (\%) & \% of US Total & \% of US Trend & Spearman's Rho $^{\mathbf{1}}$ \\
\hline Alaska & 253 & 3.1 & 0.7 & 0.4 & 0.29 \\
Northwest & -861 & -1.9 & 4.2 & -1.4 & -0.47 \\
N. California & -404 & -2.0 & 1.8 & -0.7 & -0.48 \\
S. California & -160 & -2.3 & 0.6 & -0.3 & -0.29 \\
No. Rockies & -501 & -1.7 & 2.8 & -0.8 & -0.45 \\
Great Basin & -1228 & -4.5 & 2.5 & -2.0 & -0.64 \\
Southwest & -170 & -0.3 & 6.1 & -0.3 & -0.07 \\
Rocky Mtns & 246 & 0.7 & 3.4 & 0.4 & 0.10 \\
Eastern & 4023 & 4.8 & 7.6 & 6.5 & 0.74 \\
Southern & 60,480 & 7.9 & 70.1 & 98.1 & 0.67 \\
TOTAL & 61,678 & 5.7 & 100.0 & 100.0 & 0.61 \\
\hline
\end{tabular}

${ }^{1}$ Correlation coefficients below -0.5 or above 0.5 are considered strong trends and are more meaningful than $p$-values in such a small dataset. 
a)

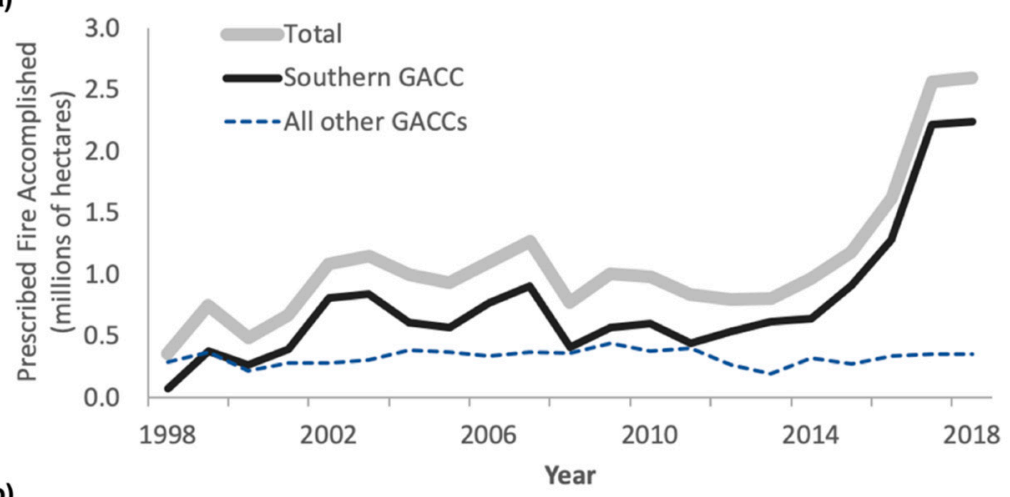

b)

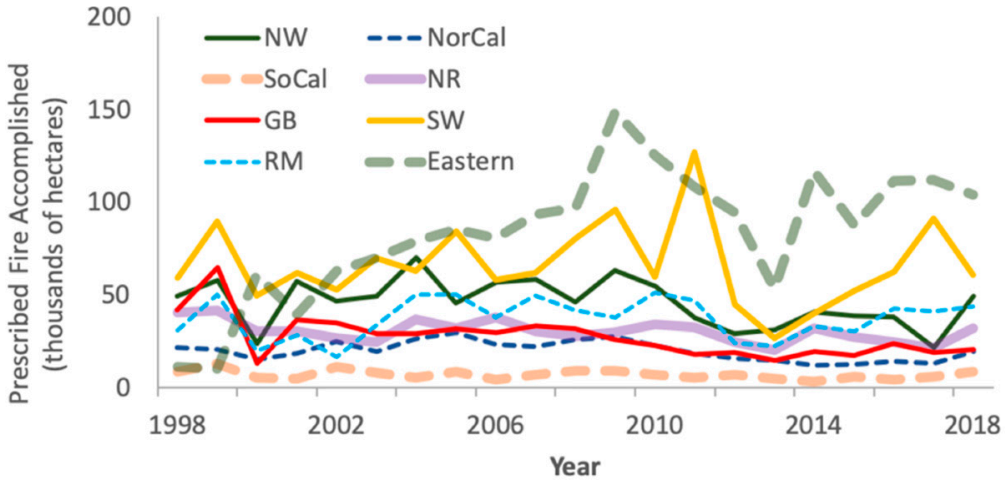

c)

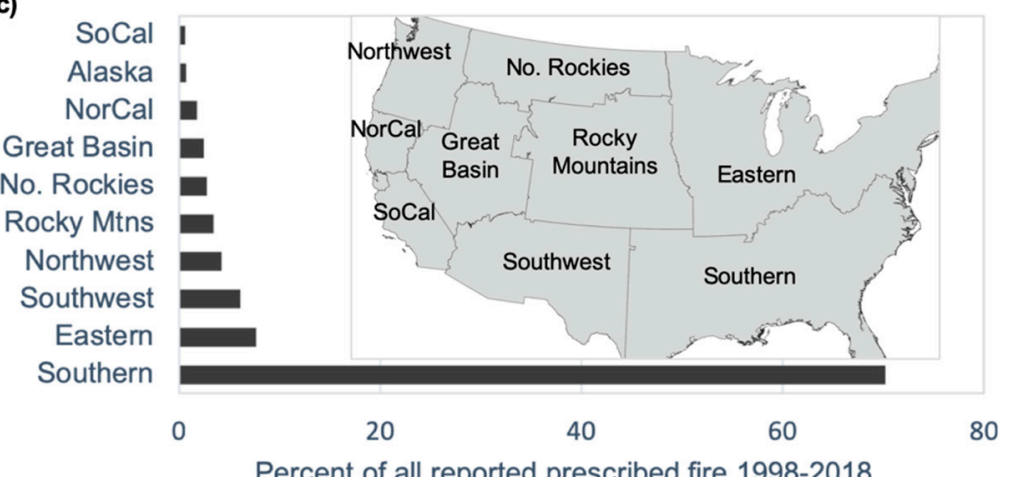

d)

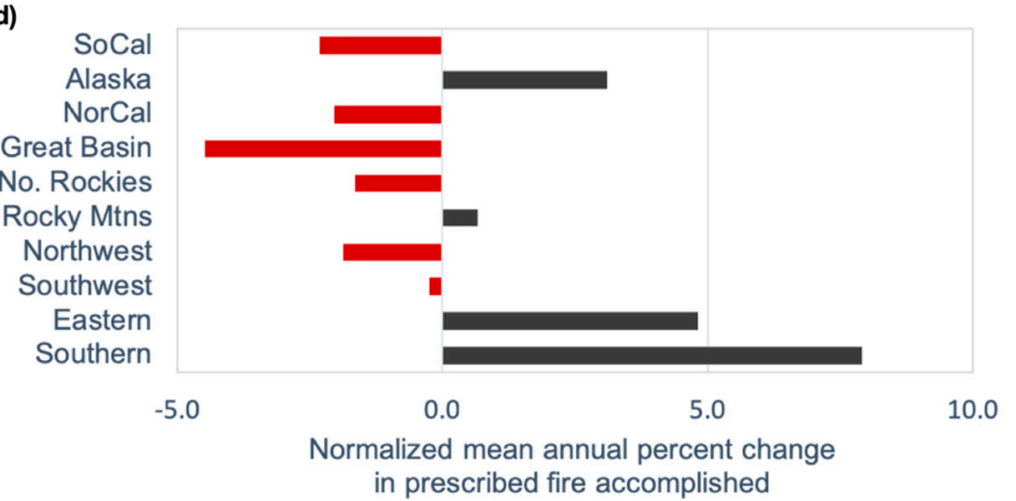

Figure 2. Prescribed fire accomplished in the United States (US) from 1998 to 2018 across Geographic Area Coordination Center (GACC) regions, including (a) total area burned (in millions of hectares), area burned in the Southern Geographic Area (GACC), and area burned in all nine other GACCs; (b) area burned (in thousands of hectares) in the eight other contiguous US GACCs (excludes Alaska and Southern); (c) proportion of all reported prescribed fire over the 21-year period by GACC; and (d) the normalized (by mean annual total accomplishment per GACC) mean annual change in prescribed fire completed, ranked by (c). 
Similarly, when stratified by agency, $39 \%$ of the 21 -year total and $93 \%$ of the increase in prescribed fire was accomplished by State/Other entities (Table 2, Figure 3). Of the primary federal land management agencies, only the BIA (relative trend $=3.7 \% ; r_{\mathrm{s}}=0.68$ ) accomplished substantially more prescribed fire over the study period. Overall, the proportion of total prescribed fire completed by US federal agencies has diminished from over $90 \%$ annually to less than $30 \%$ annually across the past two decades as the State/Other totals have steadily increased. This is unsurprising given regional trends, as less than $7 \%$ of the Southeastern US is managed by the five primary federal land management agencies (Table S1).

Table 2. Trends in prescribed fire accomplishments in the United States (US) by agency from 1998 to 2018, including raw trend (mean ha/year), relative trend (normalized by mean accomplishment for a given agency), percent of the total US accomplishment, percent of the total US trend, and Spearman's Rho to indicate the strength of the trend. Agencies are Bureau of Indian Affairs (BIA), Bureau of Land Management (BLM), Fish and Wildlife Service (FWS), National Park Service (NPS), US Forest Service (USFS), and other federal (e.g., Defense, Energy, and Reclamation), non-federal, state, and municipal agencies that report to the National Interagency Fire Center (NIFC) (State/Other, ST/OT).

\begin{tabular}{cccccc}
\hline Agency & Trend (ha/yr) & Rel. Trend (\%) & \% of US Total & \% of US Trend & Spearman's Rho $^{\mathbf{1}}$ \\
\hline BIA & 1164 & 3.7 & 2.9 & 1.9 & 0.69 \\
BLM & -1335 & -3.0 & 4.1 & -2.2 & -0.47 \\
FWS & 518 & 0.6 & 8.6 & 0.8 & 0.05 \\
NPS & 397 & 1.0 & 3.6 & 0.6 & 0.06 \\
USFS & 3353 & 0.7 & 41.3 & 5.4 & 0.09 \\
ST/OT & 57,582 & 13.4 & 39.5 & 93.4 & 0.74 \\
\hline
\end{tabular}

${ }^{1}$ Correlation coefficients below -0.5 or above 0.5 are considered strong trends and are more meaningful than $p$-values in such a small dataset.

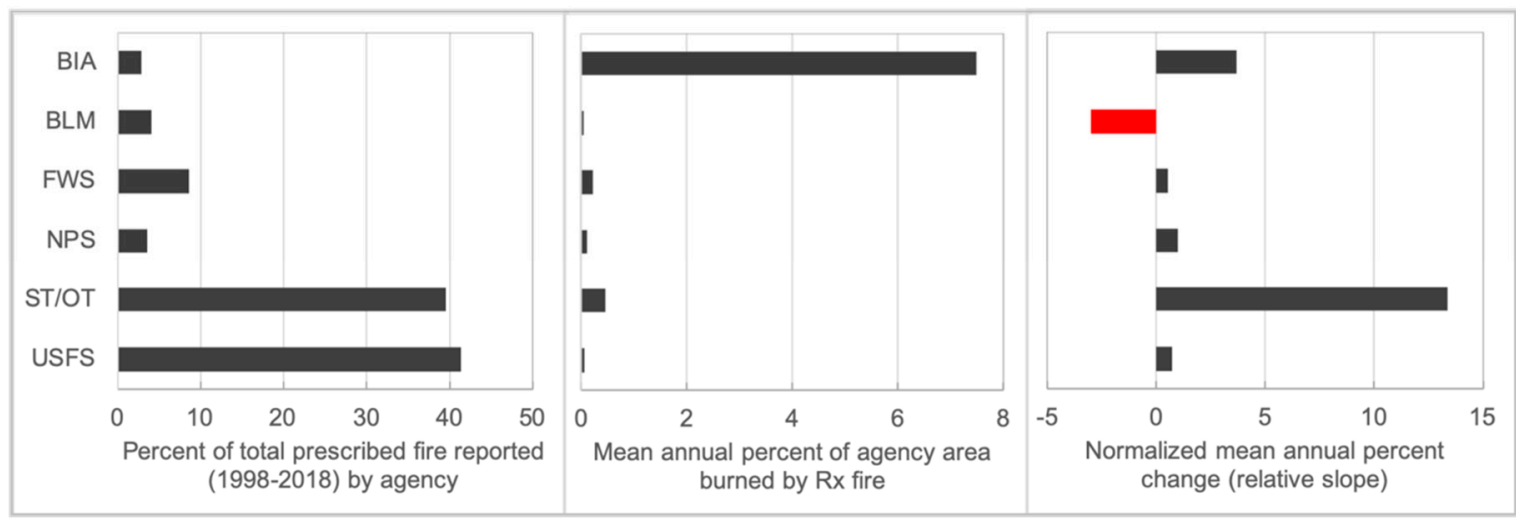

Figure 3. Percent of all reported prescribed fire nationally over the 21-year period (1998-2018) stratified by agency (left panel), mean annual percent of agency area burned by prescribed fire (i.e., area-normalized mean accomplished; center panel), and normalized (by mean annual total accomplishment per agency) mean annual change in prescribed fire completed (i.e., relative slope per agency; right panel).

\section{Discussion}

The Southeastern US accomplished over twice the amount of prescribed fire as the entire rest of the US combined between 1998 and 2018. This may be one of many reasons why the Southeastern states have experienced far fewer wildfire disasters relative to the Western US in recent years $[17,33]$. The amount of prescribed fire reported in the Southeastern US is also likely underreported, as the Southeastern states have purportedly accomplished millions of hectares of prescribed fire annually for decades [34-37]. However, until 1998 there was no central prescribed fire reporting in the US. Even after 1998, non-federal entities did not necessarily report the full scope of their accomplishments in the federal reporting system. 
The dramatic difference in prescribed fire completed between east and west reflects both a broad socio-cultural divide over fire [29] and a problematic dichotomy between federal and non-federal fire management. Biophysical conditions have often been highlighted as a challenge to prescribed burning in the Western US; the topography is more complex and inaccessible, burn windows are narrow, and fuels have built up throughout decades of fire exclusion $[23,38]$. By contrast, the Southeastern states have both the most extensive Wildland-Urban Interface in the US [39] and some of the worst air quality challenges associated with prescribed fire due to higher humidity (e.g., increased smog formation). That agencies are able to accomplish so much prescribed fire in such a populated region likely also reflects social acceptance in addition to more conducive conditions. It is also telling that no single Southern state is driving the regional trend. State summaries in the Historical Wildland Fire Summary reports indicate that Alabama, Arkansas, Florida, Georgia, Louisiana, Mississippi, North Carolina, South Carolina, and Texas all completed an average of over 40,000 ha per year each from 2002 to 2017.

Prescribed fire is widely accepted as a tool in the Southeastern states, where residents are more accustomed to using controlled fire to enhance timber production, control the rapidly growing vegetation, and enhance game species habitat $[29,34]$. Some states, such as Florida, even have laws that recognize prescribed fire as being in the public interest and protect landowner rights to utilize it [40]. Although studies throughout the US have shown that residents in all regions broadly support the concept of prescribed fire, they fear the potential for escaped fires and they are also highly concerned about smoke impacts [41]. However, Engebretson et al. [42] found significantly higher tolerance of prescribed fire smoke from Southern-state residents than those in Western states, which suggests that this tolerance may translate into less opposition to using prescribed fire in the Southern GACC. This is true for either federal or non-federal agencies in the region; the Historical Summaries indicate that much of the USFS annual prescribed fire accomplishment occurs in the Southern GACC states (particularly along the Gulf Coast) rather than in the Western states where the greatest proportion of USFS land lies.

By contrast, fire managers in the Western US face considerable social barriers to using prescribed fire, including negative public perceptions of risk of escapes and smoke [29,42]. This high perception of risk has been cemented by the occasional escaped prescribed fire, but it has likely also become entrenched due to the absence of prescribed fire demonstrated here. Fire managers, particularly federal fire managers, receive insufficient incentive to use prescribed fire under current agency policies that incentivize fire suppression (e.g., with overtime pay and promotion) but penalize risk-taking, particularly when escaped prescribed fires occur $[29,43]$. Additionally, federal funding for prescribed fire and other fuel reduction activities has been drastically depleted over the past two decades as large wildfires force federal agencies to expend allocated funds on suppression rather than prevention [35-37].

Of the federal agencies reporting individually (i.e., separate from the ST/OT class), only the BIA has been able to substantially increase the relative use of prescribed fire. This increase is particularly striking because a higher proportion of tribal lands managed by BIA have been subject to prescribed fire than for any other agency, with a mean of $7.5 \%$ of tribal lands burned each year (Figure 3 ). This may reflect the more recent efforts of tribes seeking to reclaim sovereignty on their ancestral lands through increased self-governance and drawing upon TEK to re-introduce extensive intentional fire in these landscapes [25], particularly following the 2004 Tribal Forest Protection Act [26]. The push for more prescribed fire among tribes is also reflected in the BIA budget for prescribed fire, particularly compared with the fire suppression budget. BIA devotes the second-highest budget of the five primary land management agencies to prescribed fire (behind USFS), but the prescribed fire budget is between $50 \%$ and $80 \%$ of its fire suppression budget, while no other agency's prescribed fire budget has exceeded $25 \%$ of its fire suppression budget in the last five years [44]. It is also worth noting that the more detailed Historical Wildland Fire Summary reports suggest that the strong positive trend in the Eastern GACC region is potentially partially a function of increased tribal burning in that region.

Despite changes in federal fire management policy meant to increase prescribed fire use, only one region of the US has considerably increased the amount of prescribed fire completed, and credit 
for much of this increase goes to non-federal agencies. Given the evidence that federal agencies have not accomplished more prescribed fire across the US over the past two decades, this suggests that while the Cohesive Strategy incorporates the best available science in a top-level holistic management framework, federal agencies have not made sufficient policy changes or budgetary allocations to carry out the Strategy.

There is considerable evidence in the scientific literature that prescribed fire is the most effective means of reducing the risk of wildfire disasters and increasing ecosystem resilience across much of the US. However, only one primary federal land management agency has substantially increased prescribed fire use, and the only widespread use and acceptance of prescribed fire is in the Southeastern states. Federal and non-federal entities have used the prescribed fire expertise of the Southeastern region as a training ground for fire and fuel managers across the US, but this has not translated to increased prescribed fire use. This suggests that a larger cultural shift in public sociocultural perceptions of prescribed fire is needed to truly capitalize upon the utility of prescribed fire and more aggressively reduce wildfire risk. Without such a shift, more catastrophic wildfire disasters are inevitable.

Supplementary Materials: The following are available online at http://www.mdpi.com/2571-6255/2/2/30/s1, Table S1: Hectares under each primary land management agency by Geographic Area Coordination Center (GACC) region.

Funding: This research was partially supported by the National Science Foundation through award DMS-1520873.

Acknowledgments: The author is grateful for input from John Abatzoglou and four anonymous reviewers that strengthened this paper, and for agency budget data from Maya Miller at Climate Central that improved the Discussion.

Conflicts of Interest: The author declares no conflict of interest.

\section{References}

1. Calkin, D.E.; Cohen, J.D.; Finney, M.A.; Thompson, M.P. How risk management can prevent future wildfire disasters in the wildland-urban interface. Proc. Natl. Acad. Sci. USA 2014, 111, 746-751. [CrossRef] [PubMed]

2. Moritz, M.A.; Batllori, E.; Bradstock, R.A.; Gill, A.M.; Handmer, J.; Hessburg, P.F.; Leonard, J.; McCaffrey, S.; Odion, D.C.; Schoennagel, T.; et al. Learning to co-exist with wildfire. Nature 2014, 515, 58-66. [CrossRef] [PubMed]

3. North, M.P.; Stephens, S.L.; Collins, B.M.; Agee, J.K.; Aplet, G.; Franklin, J.F.; Fule, P.Z. Reform forest fire management. Science 2015, 349, 1280-1281. [CrossRef] [PubMed]

4. Schoennagel, T.; Balch, J.K.; Brenkert-Smith, H.; Dennison, P.E.; Harvey, B.J.; Krawchuk, M.A.; Mietkiewicz, N.; Morgan, P.; Moritz, M.A.; Rasker, R.; et al. Adapt to more wildfire in western North American forests as climate changes. Proc. Natl. Acad. Sci. USA 2017, 114, 4582-4590. [CrossRef]

5. Fernandes, P.M.; Botelho, H.S. A review of prescribed burning effectiveness in fire hazard reduction. Int. J. Wildland Fire 2003, 12, 117-128. [CrossRef]

6. Pollet, J.; Omi, P.N. Effect of thinning and prescribed burning on crown fire severity in ponderosa pine forests. Int. J. Wildland Fire 2002, 11, 1-10. [CrossRef]

7. Vaillant, N.M.; Fites-Kaufman, J.A.; Stephens, S.L. Effectiveness of prescribed fire as a fuel treatment in Californian coniferous forests. Int. J. Wildland Fire 2009, 18, 165-175. [CrossRef]

8. Wiedinmyer, C.; Hurteau, M.D. Prescribed fire as a means of reducing forest carbon emissions in the western United States. Environ. Sci. Technol. 2010, 44, 1926-1932. [CrossRef]

9. Hurteau, M.; North, M. Fuel treatment effects on tree-based forest carbon storage and emissions under modeled wildfire scenarios. Front. Ecol. Environ. 2009, 7, 409-414. [CrossRef]

10. Collins, B.M.; Das, A.J.; Battles, J.J.; Fry, D.L.; Krasnow, K.D.; Stephens, S.L. Beyond reducing fire hazard: Fuel treatment impacts on overstory tree survival. Ecol. Appl. 2014, 24, 1879-1886. [CrossRef]

11. Smith, A.M.S.; Kolden, C.A.; Bowman, D.M. Biomimicry can help humans to coexist sustainably with fire. Nature Ecol. Evol. 2018, 2, 1827. [CrossRef]

12. Larson, A.J.; Belote, R.T.; Cansler, C.A.; Parks, S.A.; Dietz, M.S. Latent resilience in ponderosa pine forest: Effects of resumed frequent fire. Ecol. Appl. 2013, 23, 1243-1249. [CrossRef] 
13. Fule, P.Z.; Cocke, A.E.; Heinlein, T.A.; Covington, W.W. Effects of an intense prescribed forest fire: Is it ecological restoration? Restor. Ecol. 2004, 12, 220-230. [CrossRef]

14. Moore, M.M.; Covington, W.W.; Fulé, P.Z. Reference conditions and ecological restoration: A southwestern ponderosa pine perspective. Ecol. Appl. 1999, 9, 1266-1277. [CrossRef]

15. Abatzoglou, J.T.; Williams, A.P. Impact of anthropogenic climate change on wildfire across western US forests. Proc. Natl. Acad. Sci. USA 2016, 113, 11770-11775. [CrossRef] [PubMed]

16. Balch, J.K.; Bradley, B.A.; Abatzoglou, J.T.; Nagy, R.C.; Fusco, E.J.; Mahood, A.L. Human-started wildfires expand the fire niche across the United States. Proc. Natl. Acad. Sci. USA 2017, 114, 2946-2951. [CrossRef]

17. Bowman, D.M.; Williamson, G.J.; Abatzoglou, J.T.; Kolden, C.A.; Cochrane, M.A.; Smith, A.M.S. Human exposure and sensitivity to globally extreme wildfire events. Nat. Ecol. Evol. 2017, 1, 0058. [CrossRef]

18. Bowman, D.M.; Moreira-Muñoz, A.; Kolden, C.A.; Chávez, R.O.; Muñoz, A.A.; Salinas, F.; González-Reyes, Á.; Rocco, R.; de la Barrera, F.; Williamson, G.J.; et al. Human-environmental drivers and impacts of the globally extreme 2017 Chilean fires. Ambio 2019, 48, 350-362. [CrossRef] [PubMed]

19. Stephens, S.L.; Agee, J.K.; Fule, P.Z.; North, M.P.; Romme, W.H.; Swetnam, T.W.; Turner, M.G. Managing forests and fire in changing climates. Science 2013, 342, 41-42. [CrossRef]

20. Smith, A.M.S.; Kolden, C.A.; Paveglio, T.B.; Cochrane, M.A.; Bowman, D.M.; Moritz, M.A.; Kliskey, A.D.; Alessa, L.; Hudak, A.T.; Hoffman, C.M.; et al. The science of firescapes: Achieving fire-resilient communities. Bioscience 2016, 66, 130-146. [CrossRef]

21. Wildland Fire Leadership Council. The National Strategy: The Final Phase in the Development of the National Cohesive Wildland Fire Management Strategy; Washington, DC, USA, 2014. Available online: https://www. forestsandrangelands.gov/strategy/thestrategy.shtml (accessed on 25 April 2019).

22. Ryan, K.C.; Knapp, E.E.; Varner, J.M. Prescribed fire in North American forests and woodlands: History, current practice, and challenges. Front. Ecol. Environ. 2013, 11, e15-e24. [CrossRef]

23. Stephens, S.L.; Ruth, L.W. Federal forest-fire policy in the United States. Ecol. Appl. 2005, 15, 532-542. [CrossRef]

24. Kimmerer, R.W.; Lake, F.K. The role of indigenous burning in land management. J. For. 2001, 99, 36-41.

25. Lake, F.K.; Wright, V.; Morgan, P.; McFadzen, M.; McWethy, D.; Stevens-Rumann, C. Returning fire to the land: Celebrating traditional knowledge and fire. J. For. 2017, 115, 343-353. [CrossRef]

26. Rasmussen, K.; Hibbard, M.; Lynn, K. Wildland fire management as conservation-based development: An opportunity for reservation communities? Soc. Nat. Resour. 2007, 20, 497-510. [CrossRef]

27. Ray, L.; Kolden, C.A.; Chapin, F., III. A case for developing place-based fire management strategies from traditional ecological knowledge. Ecol. Soc. 2012, 17, 37. [CrossRef]

28. Broome, R.A.; Johnston, F.H.; Horsley, J.; Morgan, G.G. A rapid assessment of the impact of hazard reduction burning around Sydney, May 2016. Med. J. Aust. 2016, 205, 407-408. [CrossRef]

29. Kolden, C.A.; Brown, T.J. Beyond wildfire: Perspectives of climate, managed fire and policy in the USA. Int. J. Wildland Fire 2010, 19, 364-373. [CrossRef]

30. Quinn-Davidson, L.N.; Varner, J.M. Impediments to prescribed fire across agency, landscape and manager: An example from northern California. Int. J. Wildland Fire 2012, 21, 210-218. [CrossRef]

31. Haugo, R.; Kellogg, B.S.; Cansler, C.A.; Kolden, C.A.; Kemp, K.B.; Robertson, J.; Metlen, K.L.; Vaillant, N.M.; Restaino, C.M. The Missing Fire: Quantifying human exclusion of wildfire in Pacific Northwest forests, USA. Ecosphere 2019, 10, e02702. [CrossRef]

32. Parks, S.A.; Miller, C.; Parisien, M.A.; Holsinger, L.M.; Dobrowski, S.Z.; Abatzoglou, J. Wildland fire deficit and surplus in the western United States, 1984-2012. Ecosphere 2015, 6, 1-13. [CrossRef]

33. Williams, J. Exploring the onset of high-impact mega-fires through a forest land management prism. For. Ecol. Manag. 2013, 294, 4-10. [CrossRef]

34. Haines, T.K.; Busby, R.L.; Cleaves, D.A. Prescribed burning in the South: Trends, purpose, and barriers. South. J. Appl. For. 2001, 25, 149-153.

35. Melvin, M.A. 2012 National Prescribed Fire Use Survey Report; Coalition of Prescribed Fire Councils, Inc.: Newton, GA, USA, 2012; p. 22. Available online: http://www.prescribedfire.net/resources-links (accessed on 5 April 2019).

36. Melvin, M.A. 2015 National Prescribed Fire Use Survey Report; Coalition of Prescribed Fire Councils, Inc.: Newton, GA, USA, 2015; p. 22. Available online: http://www.prescribedfire.net/resources-links (accessed on 5 April 2019). 
37. Melvin, M.A. 2018 National Prescribed Fire Use Survey Report; Coalition of Prescribed Fire Councils, Inc.: Newton, GA, USA, 2018; p. 22. Available online: http://www.prescribedfire.net/resources-links (accessed on 5 April 2019).

38. Vaillant, N.M.; Reinhardt, E.D. An evaluation of the Forest Service Hazardous Fuels Treatment Program-Are we treating enough to promote resiliency or reduce hazard? J. For. 2017, 115, 300-308. [CrossRef]

39. Radeloff, V.C.; Helmers, D.P.; Kramer, H.A.; Mockrin, M.H.; Alexandre, P.M.; Bar-Massada, A.; Butsic, V.; Hawbaker, T.J.; Martinuzzi, S.; Syphard, A.D.; et al. Rapid growth of the US wildland-urban interface raises wildfire risk. Proc. Natl. Acad. Sci. USA 2018, 115, 3314-3319. [CrossRef] [PubMed]

40. Brenner, J.; Wade, D. Florida's revised prescribed fire law: Protection for responsible burners. In Proceedings of Fire Conference 2000: The First National Congress on Fire Ecology, Prevention, and Management; Miscellaneous Publication No. 13; Galley, K.E.M., Klinger, R.C., Sugihara, N.G., Eds.; Tall Timbers Research Station: Tallahassee, FL, USA, 2003; pp. 132-136.

41. McCaffrey, S.M. Prescribed fire: What influences public approval? In Fire in Eastern Oak Forests: Delivering Science to Land Managers, Conference Proceedings; Gen. Tech. Rep. NRS-P-1; Dickinson, M.B., Ed.; US Department of Agriculture, Forest Service, Northern Research Station: Newtown Square, PA, USA, 2006; pp. 192-198.

42. Engebretson, J.M.; Hall, T.E.; Blades, J.J.; Olsen, C.S.; Toman, E.; Frederick, S.S. Characterizing public tolerance of smoke from wildland fires in communities across the United States. J. For. 2016, 114, 601-609. [CrossRef]

43. Lueck, D.; Yoder, J. The economic foundations of firefighting organizations and institutions. J. For. 2015, 113, 291-297. [CrossRef]

44. Miller, M. (ClimateCentral.org, New York, NY, USA). Personal Communication, 2019.

(C) 2019 by the author. Licensee MDPI, Basel, Switzerland. This article is an open access article distributed under the terms and conditions of the Creative Commons Attribution (CC BY) license (http://creativecommons.org/licenses/by/4.0/). 